\title{
Classes, taxa and categories in hierarchical virus classification: a review of current debates on definitions and names of virus species
}

\author{
Marc H. V. VAN REGENMORTEL \\ UMR 7242 Biotechnologie et Signalisation Cellulaire, Université de Strasbourg-CNRS, 300 Boulevard Sébastien Brant, \\ CS 10413,67412 Illkirch Cedex, France<vanregen@unistra.fr>
}

\begin{abstract}
The species taxon was introduced in virus classification as late as 1991 when it was endorsed by the International Committee on Taxonomy of Viruses (ICTV). The official definition of virus species was as follows: "A virus species is a polythetic class of viruses that constitute a replicating lineage and occupy a particular ecological niche". Its key feature was that it incorporated the notion of polythetic class also known as a cluster class. Whereas monothetic classes are defined by one or a few properties that are both necessary and sufficient for membership in the class, polythetic classes are defined by a variable set of statistically covariant properties, none of which is a defining property necessarily present in every member of the class. Since a virus species class is a conceptual construction, it cannot be described by its physical or material properties and can only be defined by listing certain properties of the viruses that are its members. Properties used for defining virus species are properties of viruses that can be altered by a few mutations, such as their natural host range, pathogenicity, mode of transmission and small differences in the viral genome. This means that these species-defining properties vary considerably in different members of the same virus species. Since higher taxa such as genera and families have more viruses as members than species taxa, they require fewer defining properties than species taxa which require more properties to meet the qualifications for membership. The logical principle that increasing the number of qualifications decreases membership invalidates the claim that a single property could be sufficient for defining a virus species.

The bionominalist school of thought which claims that species are individuals instead of classes is examined and it is concluded that bionominalism does not provide a useful framework for classifying viruses. Since large numbers of sequences of viral genomes have become available, many attempts are currently made to establish species solely on the basis of genome data obtained from putative members of a viral species. Since the nucleic acid sequence present in a virus particle is part of the phenotype of the virus, a virus classification based on nucleotide sequences is a phenotypic classification that relies on molecular sequences rather than on the morphological and biological properties of viruses. Since it is not possible to infer the phenotypic properties of a virus from its genome sequence, a genome-based classification which privileges phylogeny is actually a classification of viral genomes rather than a classification of viruses.

In recent years, it has been suggested that it should be possible to define a virus species monothetically by a single species-defining property such as a genome nucleotide motif and that the term 'polythetic' should therefore be removed from the official species definition. In 2013, the ICTV ratified the following new definition of virus species: " $A$ virus species is a monophyletic group of viruses whose properties can be distinguished from those of other species by multiple criteria". Since every virus species, genus or family could be considered to be a monophyletic group, this was actually a definition of 'virus taxon' instead of virus species. Many objections were raised against this new species definition and these are available on the ICTV website. A major concern was that 'polythetic class' in the earlier definition had been replaced by 'group' of viruses, because a group is a collection of viruses that are linked by a part-whole relation, whereas the term class implies the logical relations of class membership and class inclusion used in all hierarchical classifications. The authors of the new definition actually claimed that the term class should be used only to denote a category in the classification hierarchy, above the category order and below the category phylum. Examples were also
\end{abstract}


given of the pernicious consequences that followed from the fact that new species could now be established on the basis of a single criterion of nucleotide sequence similarity in viral genomes.

In 1998, the ICTV introduced species names that differed from virus names only by typography, with the result that measles virus became officially a member of the species Measles virus (italicized, with a capital initial). This led to considerable confusion and the ICTV subsequently agreed that its Study Groups in charge of the taxonomy and nomenclature of individual virus families could propose non-Latinized binomial names (NLBNs) for species in certain virus genera. Such NLBNs, which had been used unofficially for 50 years, are obtained by replacing the terminal word 'virus' that occurs in all common English virus names with the name of the genus to which the virus belongs, which also ends in -virus. Measles virus thus became a member of the species Measles morbillivirus which was more easily recognized as a species name since binomial names in biology are associated with taxonomic species names. In the last four years, numerous species NLBNs have been introduced in several virus families.

Key words: Virus taxonomy, Linnaean hierarchy, International Committee on Taxonomy of Viruses (ICTV), bionominalism, polythetic class, virus identification, viral phenotype, DNA barcoding, viral genomes, species-defining properties, begomoviruses, non-Latinized binomial species names

\section{Introduction}

The branch of philosophy known as ontology deals with the nature of things and of reality and if biologists want to be able to answer questions about the nature of life, of species or of consciousness, they need to be familiar with the ontological postulates underlying their discipline. Classification deals with abstract classes and taxonomy deals with classes called taxa. Viral taxonomy refers both to the scientific discipline of virus classification and to the outcome of a classification activity involving viruses.

Virus classification deals with abstract classes of viruses that are conceptual constructions of the mind. The most important characteristic of such classes is that they have members which are the concrete viral objects studied by virologists. Every membership condition determines a class and if a virus has a monopartite negative strand RNA genome, it automatically becomes a member of the Mononegavirales which is a class known as an order (Fauquet 2010). Such a class is not physically real and must not be confused with the viruses themselves. Similarly, the abstract concept of a virus species as a class of viruses should not be confused with the viruses which are the concrete members of the species. Confusions between different logical categories have been a fertile source of misunderstandings in viral taxonomy. It has been claimed, for instance, that the name tobacco mosaic virus is an abstraction because only its particles can be handled (Bos 2003; Van Regenmortel 2003). Such a claim arose because the term 'virus' was not recognized to be what logicians call a general term, i.e. a word that denotes any number of concrete entities (Quine 1960: 90-105).

Section 2 of this review will clarify the logical relations that exist among individual viruses, among the classes of these viruses called taxa and among the classes of these classes called categories. Since virus classification follows the structure of the Linnaean hierarchy, the logical structure of this hierarchy described by Buck \& Hull (1966) will be outlined.

Section 3 examines the popular bionominalist school of thought which takes species to be concrete individuals with a definite spatiotemporal localization instead of timeless, abstract classes. The ontology advocated by Mahner \& Bunge (1997: 253-270) will be briefly described, leading to the conclusion that bionominalism does not provide an adequate framework for classifying viruses.

Section 4 relates how the concept of virus species as a polythetic class of viruses became accepted in viral taxonomy and was endorsed by the International Committee on Taxonomy of Viruses (ICTV) which is the body empowered by the International Union of Microbiological Societies (IUMS) to make decisions on matters of virus classification and nomenclature (Pringle 1991).

Section 5 explains that since the properties used for demarcating individual virus species tend to vary because they are easily modified by a few mutations, it is not possible to define virus species by relying only on one or a few necessary and sufficient conditions for establishing species membership. 
Section 6 examines the currently fashionable trend to use small parts of a viral genome for defining virus species and emphasizes that classifying viral genomes should not be confounded with classifying pathogens such as viruses.

Section 7 describes the current debate surrounding a recently introduced and controversial new definition of virus species and section 8 reviews the widespread introduction of non-Latinized binomial ${ }^{1}$ names for virus species.

\section{The logic of hierarchical virus classification}

The root of the word classification is class, a term that refers to all the classes of viruses or organisms that have concrete objects as their members. Every membership condition determines a class and since whatever is said about a thing ascribes a property to it, properties and classes are related entities (Quine 1990: 22-24). Bionominalists, however, deny that species are classes (see section 3) although they consider genera and families to be classes since a taxonomy otherwise becomes impossible (Bernier 1984).

Class membership is the logical relation that makes it possible to establish a bridge between two logical categories, namely an abstract class or taxon which is a mental construct and its concrete members that are objects located in space and time. This membership relation is different from the part-whole relationship that exists between two concrete objects, one being a part of the other in the way that a limb is part of a body. It is not possible for a viral object to be a part of a conceptual species construct, nor is it possible for a thought or concept to be part of a material object (Quine 1960: 118-124).

The taxonomic identification of a virus may lead, for instance, to the statement that a virus is a member of a certain virus species which is the lowest taxon category in a hierarchical classification. Since the species taxon is already a class, it is a member of the species category which is the class of all species taxa. The relation that individual viruses have to taxa is the same membership relation that taxa have to their respective categories, the members of the category species being all the species taxa (Buck \& Hull 1966).

Virus taxonomy makes use of a hierarchy of taxa, the lowest taxon being a virus species followed by higher taxa such as virus genera, families and orders. The viruses that are members of a species taxon are also members of a genus taxon immediately above it as well as members of a higher family or order category. Similar species are collected in a genus, similar genera into a family and similar families into an order.

The relation between a lower taxon and a higher taxon immediately above it is called 'class inclusion' which is a crucial relation in the logic of a hierarchical classification. To say that the species Measles virus is included in the genus Morbillivirus is to say that the properties required for classifying a virus as a member of the species Measles virus include, besides others, all the properties required to classify it as a member of the genus Morbillivirus. The lower taxon, having fewer viruses as members, requires more properties to meet the qualifications for membership. This situation illustrates the logical principle according to which reducing the number of required qualifications increases membership whereas increasing the number of qualifications decreases membership (Buck \& Hull 1966). The genus Morbillivirus can thus be regarded as a class generated by relaxing the membership requirement for being a member of the species Measles virus. Class inclusion in the Linnaean hierarchy obviates the need for repeating the properties used for defining higher taxa in the definitions of the lower taxa included in them, although all these properties are still necessary for membership in the lower taxon. It should be noted that this principle invalidates the claim that a single property may be sufficient for defining a virus species (see sections 5 and 6). Higher taxa such as virus families and orders can usually be defined by a small number of stable, invariant properties that are both necessary and sufficient for membership in the class, which is the reason why these classes tend to be viewed as universal classes. Membership in such classes is thus easier to establish than membership in a virus species. It must be

1. The term 'binomial' traditionally used in viral taxonomy is here preferred to the term 'binominal' usually employed in Bionomina. 
emphasized that the relation of class inclusion does not mean that the defining properties of a species are also automatically defining properties of a genus since the invariant properties of genera that are also present in species are not discriminating defining properties of species taxa but of genus taxa. Furthermore, the taxonomic categories of species, genera, families and orders which are classes of classes are not included in each other since these categories are mutually exclusive classes. It is thus impossible, for instance, for the categories species and genus to have any taxa members in common (Buck \& Hull 1966).

\section{Bionominalism: are species classes or individuals?}

The school of thought known as bionominalism considers that since species change during evolution, giving rise to new species, they must be evolving historical entities with a temporal dimension rather than immutable and timeless classes. This gave rise to the view that species are concrete individuals rather than abstract classes (Ghiselin 1974; Hull 1976) and changed the ontological status of species which no longer were considered to have viral objects as their members since viruses were now actually part of a material species. Mahner \& Bunge (1997: 232-270) analyzed in great detail the numerous consequences of this altered ontology of species-as-individuals (SAI). First, it is no longer possible to define species since only abstract concepts can be defined intensionally (see section 5), with the result that only the proper names of taxa can be defined and not the taxa themselves (Buck \& Hull 1966). Second, viruses are then linked to species taxa by part-whole relations instead of membership relations, which undermines the traditional view that classes, taxa and any resulting classification are conceptual constructs rather than real objects. The SAI thesis also holds that species are lineages of ancestral-descendant populations with a spatiotemporal location and that all taxa are so-called historical entities forming cohesive wholes (Hull 1988; de Queiroz \& Donoghue 1988). The notion of historical entity takes the history and lineage of a thing to be a concrete individual which is an instance of reification. However, the history of a population is not a concrete system and the relation of antecedence is not a bonding but only a temporal relation. Mahner \& Bunge (1997: 238) argued that the relational concepts of ancestry, progeny and lineage are actually not real objects and that the so-called 'genealogical nexus' is not a bonding or causal relation since the ancestry and progeny of a population cannot act upon each other unless they exist at the same time. Descent is not a causal relation since causality relates only events and not things, the caterpillar not being the cause of the butterfly. Species also cannot descend from each other in a literal sense since only concrete organisms or viruses can do so. When the only necessary and sufficient property for belonging to any taxon is descent from a common ancestor, it has been suggested (Ruse 1987) that descent may have become the new essence of the anti-essentialists.

Since a classification is only a conceptual construct, taxa can be considered to be real individuals only when concepts are conflated with their referents. The major shortcoming of bionominalism is that it fails to distinguish between species as concrete entities and species as abstract entities, i.e. it does not distinguish a thing from its conceptual representation. Philosophers tend to carve up the world according to their preferred logical dichotomies which they consider to be fundamental. The popular dichotomy of 'abstract universal' versus 'concrete particular', however, fails for instance to clarify the nature of the Earth's equator and the dichotomy of 'class' versus 'individual' applies only when universal, Aristotelian classes are considered (Van Regenmortel 2010a). On the other hand, it is also possible to conceive of and establish classes of objects that exist on Earth for only limited amounts of time and species are clearly such classes. The class of paintings belonging to the French impressionist school is another example of a class with an historical dimension. As argued by Mahner \& Bunge (1997), there is indeed good evidence that the mistaken ontology underlying bionominalism is responsible for its inability to provide an adequate philosophical framework for any biological classification. 


\section{The virus species problem}

The term species is universally used to denote a very low category in all biological classifications-although not always the lowest, as categories like subspecies, variety and form are used in botanical nomenclature, and subspecies in zoological nomenclature. Viruses, although not being alive (Van Regenmortel 2016), are considered to belong to biology, and as such they are classified using the categories species, genus, family and order employed in biology. In the case of genera and families, virologists readily accept that these categories are conceptual constructions of the mind that should not be confused with real objects. It seems obvious, for instance, that a virus family cannot be purified, centrifuged, sequenced or visualized in an electron microscope. Concepts like virus species, on the other hand, are often viewed as more 'real' than genera and families because they tend to be perceived as individual kinds of viruses infecting particular hosts. Some philosophers claim that concepts and objects can both 'exist' because of the ambiguity of the term 'exist' (Quine 1960: 131). The resulting confusion between species as an abstract class or category and species as concrete objects is common in the whole of biology (see section 3) and attempts to resolve this confusion by devising a satisfactory definition of species is a problem that exists not only in virology. Darwin regarded the species category to be no more real than the categories genus and family and his unwillingness to argue over the definition of species has been called a modern solution to the species problem (Ereshefsky 2009). However, the question whether species are real biological entities independent of any human conceptualization remains a hotly debated issue as illustrated for instance in the published exchange between Claridge (2010) and Mishler (2010). The question of the nature of species in zoology has recently been discussed by Dubois (2011).

Biological species have been traditionally considered to be populations whose members can only breed among themselves and are reproductively isolated from those of other populations (Mayr 1970). Since such a definition applies only to organisms that reproduce sexually, it was later modified to make it applicable to asexual organisms as follows: "A species is a reproductive community of populations, reproductively isolated from others, that occupies a specific niche in nature" (Mayr 1982).

In the 1980 s, the view that there could be virus species was rejected by plant virologists because they assumed that the biological species concept of Mayr (1970) defined by sexual reproduction, gene pools and reproductive isolation was the only legitimate species concept, which was clearly not applicable to viruses that are replicated as clones (Milne 1984). Another reason why plant virologists were opposed to species being introduced in virus classification was their belief that using the species category would bring about the use of Latin species names which they strongly opposed (Matthews 1983). According to a past president of the ICTV, nothing releases adrenalin more readily for many virologists than the suggestion that the names of viruses should be Latinized (Matthews 1985a). Although the first ICTV Reports (Wildy 1971; Fenner 1976) advocated a Latinized viral nomenclature, Latinized virus species names were not introduced and in the Fifth ICTV Report (Francki et al. 1991) the rules regarding the use of Latin in virus taxonomy were removed, opening the way for the acceptance of virus species by plant virologists.

It is somewhat paradoxical that plant virologists who strongly opposed the introduction of species in virus taxonomy had for many years been engaged in a successful demarcation of hundreds of separate plant viruses in the form of the CMI/AAB (Commonwealth Mycological Institute / Association of Applied Biologists) descriptions. Instead of accepting that these separate entities corresponded to separate taxa, the authors referred to them as 'viruses', the inverted commas indicating that each new description was a genuine new virus and not merely an additional viral strain or isolate of a previously described virus. According to Matthews (1985b), these 'viruses' really represented de facto species and the plant virologists were actually ahead of the animal virologists in delineating virus species (Van Regenmortel 1989). However, instead of using the terms species and family, plant virologists preferred to call them 'viruses' and virus groups.

Another reason for the reluctance of many virologists to use the concept of species in virus classification was the absence of a virus species definition acceptable by the ICTV. Many definitions had been proposed but none gained general acceptance. A popular textbook of plant virology (Gibbs \& Harrison 1976) proposed that "virus species are strains whose properties are so similar that there seems little value in giving them separate 
names". This definition suggested that attributing names to virus species was the same activity as developing a taxonomy. The Fourth ICTV Report (Matthews 1982) gave the following definition: "A virus species is a concept that will normally be represented by a cluster of strains from a variety of sources, or a population of strains from a particular source, which have in common a set of stable properties that separate the cluster from other clusters of strains". This definition actually only replaced undefined species by undefined strains. Another definition proposed that "A virus species is a population of viruses sharing a pool of genes that is normally maintained distinct from gene pools of other viruses" (Kingsbury 1985), which was also deemed unsatisfactory because many viruses are replicated entirely by clonal means and do not possess gene pools.

In 1989, the following definition was proposed: "A virus species is a polythetic class of viruses that constitute a replicating lineage and occupy a particular ecological niche" (Van Regenmortel 1989). This definition indicated that the members of a virus species are not simply phenetically similar objects devoid of a common origin but are collections of objects related by common descent. It also incorporated the notion of a shared ecological niche (Colwell 1992) used by Mayr in his species definition, which is a relational, functional property of an organism or a virus rather than a vacant space waiting to be occupied (Mahner \& Bunge 1997: 181-185). However, the main novelty of the 1989 species definition was that included the notion of polythetic class which by then had become generally adopted by taxonomists (Beckner 1959; Hull 1976: 178-180). Whereas monothetic classes are universal classes defined by one or a few properties that are both necessary and sufficient for membership in the class, polythetic classes are defined by a variable combination of properties, none of which is a defining property necessarily present in every member of the class. This means that (1) each member of a polythetic species shares a certain number of properties, (2) each property is present in a large but unspecified number of members and (3) no property is necessarily present in all the members of the class and absent in the members of other classes (Fig. 1). It should be stressed that the term polythetic only describes a particular distribution of properties present in a class and that the members of a class do not themselves possess polythetic or monothetic properties (see section 7). Likewise, being a genetic parasite or having a vector are properties of viruses and not of classes. A concept like a species class cannot have physical or material properties but its members do. This means that species cannot be described but can only be defined by listing certain properties of their members. The viral objects that the concept refers to are thus the concrete instances that satisfy the membership conditions of the class.

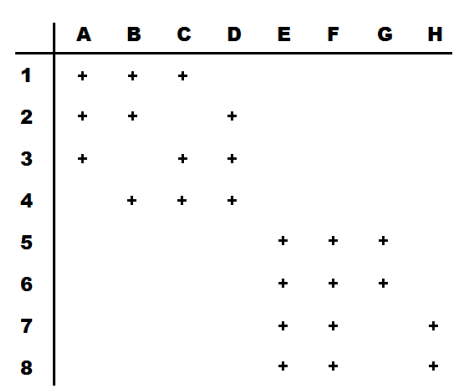

FIGURE 1. Distinction between polythetic and monothetic classes in the case of 8 individuals (1-8) and 8 properties $(\mathrm{A}-\mathrm{H})$. The possession of a property is indicated by a plus sign. Individuals $1-4$ constitute a polythetic class, each member possessing 3 out of 4 properties with no common property being present in all the members. Individuals 5-6, 7-8 and 5-6-7-8 form three monothetic classes with respectively 3, 3 and 2 properties present in all the members (Van Rijsbergen 1979; see also: http://www.iva.dk/bh/lifeboat_ko/CONCEPTS/monothetic.htm).

In 1991, the definition of species as a polythetic class was endorsed by the ICTV and species became the lowest level in virus classification (Pringle 1991). Unfortunately, many virologists thought that this definition would provide them with guidelines for establishing and demarcating new virus species and for deciding whether a virus was a member of a particular species. This misunderstanding led to a never ending debate about the presumed usefulness of a species definition for creating new species taxa and identifying their members (see sections 5 and 7). 
The concept of polythetic class, also known as a cluster class, is well-established in taxonomy (Beckner 1959; Hull 1976; Van Regenmortel 2010a) and was used successfully by ICTV Study Groups for establishing many new virus species (Ball 2005). It has also been repeatedly emphasized that the members of a polythetic virus species possess a consensus set of statistically covariant properties but not a single, species-defining property which is necessary and sufficient for membership in the class and absent in other classes (Van Regenmortel et al. 1997; Van Regenmortel 2000, 2003, 2007, 2010b; Van Regenmortel \& Mahy 2004). Nevertheless, a few virologists objected to species being called polythetic classes because they claimed that the term polythetic, commonly used in taxonomy, was obscure and not widely understood. It was also claimed that virus species could be defined monothetically by the presence of a certain nucleotide motif in a viral genome, and this led to the proposal that the term polythetic should be removed from the species definition (Gibbs \& Gibbs 2006). However, if one accepts that the presence of a nucleotide motif on its own is sufficient for defining a virus species, one reduces the concept of species to a small set of nucleotide units which is of little use to laboratory virologists who try to bring some order in the bewildering biological variety of the virus world. Although there as considerable opposition to the removal of the polythetic principle (Van Regenmortel et al. 2013), the ICTV in 2013 introduced a new definition of virus species which no longer included the notion of polythetic class (see section 7).

\section{Properties used for defining virus species and identifying individual viruses}

Properties are possessed by things and objects and cannot be detached from them. Intrinsic properties (or characters) such as chemical composition are possessed regardless of other things whereas relational properties (or relacters; Dubois 2011) such as being a genetic parasite or being vector-borne are possessed by virtue of the relation of a virus to other things such as a host or a vector.

Some philosophers distinguish a property from a predicate or attribute which they view as the conceptual representation of a thing's property. This distinction is important because not all predicates represent properties of real things. A thing either possesses property $\mathrm{P}$ or does not possess it but it cannot possess the property 'not $\mathrm{P}$ ' since there are no negative properties. However, for every predicate, there is another predicate which is the negation of the first. Negation for instance may affect the proposition 'tapeworms think' but not the property of thinking (Mahner \& Bunge 1997: 10).

The terms character, feature and trait are often used in the sense of both property and part although a part of a thing is a thing and not a property (Fristrup 1992). The notion of character has been called the central mystery of taxonomy (Inglis 1991) and although the possession of a certain part can be viewed as a property, it is not clear, for instance, if a complete genome sequence, a particular nucleotide motif, or the presence of a certain nucleotide in a viral genome should count as a single character (Gibbs et al. 2004; Van Regenmortel 2006, 2007). It has been claimed, for instance, that because the genome of a curtovirus contains 2930 nucleotides, this represents 2930 discrete bits of information that allows the virus to be classified with "total objectivity" (Varsani et al. 2014).

Only classes and concepts can be defined whereas their individual members or any other concrete objects can only be described. Taxa are defined intensionally by sets of properties that provide the qualifications for membership in the class. The intension of a concept such as class is its meaning or definition which, however, does not give it any reality outside the realm of intellectual constructions. The extension of the class is the set of members of the class, for instance the real viruses it refers to, which are the concrete referents of the class. Since the intension of a class determines its extension, the extension of a class can only be determined if one can distinguish members from non-members, which means that intension must precede extension (Mahner \& Bunge 1997: 227). A species taxon must first be established and defined by taxonomists before it becomes possible to ascertain if a sufficient number of the species-defining properties are present in an individual virus to make it a member of the species. The proposal that a monothetic (instead of a polythetic) species class can be established by relying on a single defining property such as a particular nucleotide motif found in viral 
genomes (Gibbs \& Gibbs 2006) overlooks the fact that it would be necessary to know beforehand that this motif is present in all the members of the species and absent in other species, which means that the extension would need to precede the intension which is in fact not possible (Van Regenmortel 2006, 2011).

Properties useful for distinguishing individual species within a genus obviously cannot be the stable and invariant properties used for defining genera (such as the method of virus replication or the morphology of virus particles) that are the same in all the members of the genus. Properties used for defining virus species are properties of viruses that can be altered by a few mutations, such as natural host range, cell and tissue tropism, pathogenicity, mode of transmission, small genome differences, etc. These species-defining properties, therefore, also tend to vary considerably in different members of the same species which is the very reason why species are defined polythetically by a variable combination of properties. Since they are defined by an indefinite number of statistically covariant properties, species are considered the best examples of cluster classes (Hull 1976; Pigliucci 2003). A cluster class is defined by a cluster of properties, the majority of which may be present in all members of the class although some properties can be absent in individual members. Since all the species-defining properties are not necessarily present in every member of a species, viral taxonomists may have to create species by drawing boundaries across a continuum of phenotypic and genomic variability which often involves a strong subjective element (Van Regenmortel 2007, 2010b).

The continuous nature of biological variation often leads to an absence of clear-cut discontinuities between closely related species which could then be considered as fuzzy classes with blurred boundaries. However, this would not justify abandoning the species concept since the continuous nature of electromagnetic radiation or of geological formations does not prevent us from recognizing different colours or individual mountains (Quine 1960: 125; Van Regenmortel 2007).

The demarcation of a species taxon by a virologist using the polythetic criterion should not be confused with the task of identifying a virus isolate as a member of a species. Once a species taxon has been established, it becomes possible to compare the properties of members of the species in order to discover one or more so-called diagnostic properties (Ghiselin 1974; Van Regenmortel 1990, 2000) that may suffice to identify the virus. Such diagnostic markers could be a specific reaction with a monoclonal antibody (Dekker et al. 1997) or a particular nucleotide motif (Gibbs et al. 2004), although these are not properties that could be used to establish a species taxon beforehand. The technique known as DNA barcoding (Hebert \& Gregory 2005) is sometimes presented as providing a useful additional character for establishing new species although it is only a tool for identifying members of recognized species. Nucleotide motifs cannot be used for distinguishing and establishing new species amidst the thousands or millions of species that have not yet been sequenced or recognized on the basis of phenotypic or other criteria (Ebach \& Holdrege 2005; Van Regenmortel 2011).

\section{A virus species cannot be defined solely by the properties of viral genomes}

It is now commonly accepted that virus classification should reflect the phylogenetic relationships among viruses which can be established from the sequence divergence observed in viral genomes (Gorbalenya 2010; Villareal 2010). As more sequences of viral genomes became available, attempts were made to establish species only on the basis of genome data obtained from putative members of a viral species. As explained in section 3, this cannot succeed since it is not possible to derive the intensional definition of a species from its extension. The DNA or RNA sequence present in a virion is part of the phenotype of the virus since it is a part of the virion chemical structure. Phenotypic properties include the morphology and molecular composition of the virion as well as the biochemical activities of the virus and all its relational interactions with hosts and vectors. A virus classification based on nucleotide sequences present in a virion is thus a phenotypic classification based solely on molecular sequences rather than on biological and functional properties (Mahner \& Bunge 1997: 287). There is no reason to assume that when virus species are demarcated only on the basis of genome sequences and a derived hypothetical phylogeny, this will necessarily produce a 
classification that is more correct, relevant or useful than a classification based on all the phenotypic properties of a virus (Calisher et al. 1995). Genome characteristics do not by themselves justify taxonomic allocations and the wish to record phylogeny should not overshadow the importance of other phenotypic and biological properties which are the main reasons why virologists classify viruses and engage in species demarcation.

It is impossible to infer the total phenotype of a virus from its genotype because a phenotype is not simply the manifestation or expression of a genotype but depends also on numerous contributions of extraneous epigenetic factors present in the environment and in viral hosts and vectors. This makes the phenotype the result of an ontogenic development involving both genetic and non-genetic factors (Lewontin 1992; Wolf 1995; Neumann-Held 2001). It is sometimes claimed that most, if not all, biological properties of a virus could, at least in theory, be deduced from the sequences of its viral genome and encoded proteins. This is in fact not the case since it is impossible, for instance, to predict from the sequence of encoded viral proteins which receptors of a virus determine its host and tissue specificity, as this would require prior knowledge of which host and tissues the virus is able to infect. The receptor binding site of a virus is a relational structure existing by virtue of a relation with cellular receptors in the infected host. It is equally impossible to deduce the immunological properties of a virus or to predict how the immune system of a host is likely to react to a viral infection simply by predicting the presence of conformational epitopes in an encoded viral protein using ineffectual bioinformatic algorithms (Ponomarenko \& Van Regenmortel 2009).

In his analysis of the relationship between a unit of genotype that is genetically expressed and a unit of phenotype, Moss $(2001,2003)$ argued that the metaphor of a gene as a code and information carrier arose from a conflation of two distinct meanings of the term gene which he called Gene-P and Gene-D. The Gene-P is defined by its relationship to a particular phenotypic character but does not entail the presence of a specific nucleic acid sequence able to initiate a series of developmental steps leading eventually to the phenotype. The classic example of this is the elusive Gene-P for blue eyes where the blue colour results from the absence of a DNA sequence necessary for making a brown eye pigment. There may be many structural reasons for the absence of such a sequence and any one of them could count as a genetic factor for blue eyes. Speaking of a gene in the sense of Gene-P may nevertheless be useful because it allows predictive talk about the likelihood of some phenotypic property (Moss 2003: 44).

A Gene-D, on the other hand, is defined by its molecular sequence and is a developmental resource (hence the ' $\mathrm{D}$ ') which, however, cannot on its own determine the phenotype. A Gene-D does not specify the numerous transcriptional complexes that may result from differential RNA splicing nor all the intermediate products needed to achieve the ultimate phenotypic outcome. Phenotypes are achieved through the complex interaction of many factors and Gene-D sequences are not adequate substitutes for other phenotypic properties.

When the concepts of Gene-P and Gene-D are conflated, it may give the impression that the entire chain of reactions that lead from transcriptional units to a phenotype has been elucidated although this is hardly ever the case. In fact, Gene-P is only a predictor device for some phenotype while Gene-D sequences do not specify all the developmental steps involved in producing the phenotype.

Taxa produced only on the basis of genome sequences may thus not necessarily agree with taxa established using in addition biological and other phenotypic properties such as virion structure or functional properties expressed during the assembly and maturation of virus particles. There is evidence, for instance, that a classification based on both genome sequences and structural phenotypes might reveal additional evolutionary connections that are not detectable when only sequence-based approaches are used (Krupovic \& Bamford 2010, 2011).

In conclusion, it should be evident that if only sequences of viral genomes are taken into account, this will produce a classification of viral genomes rather than a classification of viruses. Viruses should not be reduced to sequences and there is no justification for the claim that a genome-based classification which privileges phylogenetic considerations makes it superfluous to utilize all the known discriminating phenotypic properties of viruses for establishing species and other virus taxa. 


\section{The new ICTV definition of virus species}

In 2004, it was reported that all the RNA genome sequences of viruses belonging to the species Tobacco mosaic virus possessed a unique nucleotide combination motif (NC-motif) of 47 nucleotides, present in the viral polymerase gene. This NC-motif could be used for identifying all the members of that species and for distinguishing them from members of other species in the Tobamovirus genus (Gibbs et al. 2004). Other NCmotifs were also found to be diagnostic markers for identifying viruses assigned to other species in the Tobamovirus genus and one NC-motif was found that could identify any member of that genus. These findings led Gibbs \& Gibbs (2006) to propose that a virus species could be defined monothetically by the presence in all the members of the species of a common NC-motif which they considered to be a speciesdefining property that was both necessary and sufficient to establish membership in the species. They removed therefore the term polythetic from the ICTV definition in use since 1991 and proposed the following so-called 'broader' definition: "A virus species is a class of viruses that constitutes a replicating lineage and occupies a particular ecological niche". This was presented as the intensional meaning or definition of the concept of species class, based on the assumption that a part of a viral genome is a monothetic property, necessarily present in every member of the class. However, this implied that the extension of the class had to be known beforehand (see section 5). An additional problem with this broader definition is that only viruses, but not abstract species classes, are actually able to 'constitute a lineage' or 'occupy an ecological niche'. Furthermore, it seems that the authors removed the term polythetic from the initial definition because they thought it meant a type of variable property rather than a certain distribution of properties (section 4$)$. When the proposal was posted on the ICTV website, it elicited unfavorable comments and it was subsequently not approved by the ICTV. In 2011, another species definition was proposed on the ICTV website, i.e.: " $A$ virus species should be defined on the basis of a range of criteria to ensure that the viruses assigned to it form a phylogenically distinctive lineage". This definition was presented not as a definition of an abstract species class but as a rule explaining what is required in practice to establish a new species. The proposers assumed that in order for viruses to constitute a lineage, they must have inherited shared properties from a common ancestor which made the species a monothetic rather than a polythetic class. Conserved parts of viral genomes were once again regarded as adequate species-defining properties and no additional criteria were proposed that could be used to demarcate different species. This proposal was also not accepted by the ICTV.

In July 2012, another proposal by four members of the ICTV Executive Committee, A. King, M. Adams, E. Lefkowitz and E. Carstens, was posted on the ICTV website (King et al. 2012a) which included the following new definition of virus species: "A species is a monophyletic group of viruses whose properties can be distinguished from those of other species by multiple criteria". The authors acknowledged that these criteria could be genome properties and any other phenotypic properties of viruses but they no longer included the requirement that the viruses had to form a polythetic group characterized by the absence of a single defining property necessarily present in all the members of the species. As a result, it became possible to establish species as monothetic groups of viruses that shared only one or a few common defining properties. For instance, if two anelloviruses possessed only $65 \%$ nucleotide identity in their genomes, this sole criterion was sufficient to allocate them to two different species even in the absence of any known difference in other biological or phenotypic properties. Furthermore, since every species, genus and family can be considered to be a monophyletic group, King et al. (2012a) had in fact coined a definition of virus taxon instead of virus species. Another reason why monophyly is not a valid criterion for species demarcation is the common occurrence in many viruses of recombination and reassortment among parts of viral genomes which produces chimeric viruses with polyphyletic genomes (Calisher et al. 1995). This makes it impossible to accurately represent such multi-dimensional phylogeny in a monophyletic scheme (Ball 2005). Many comments were posted on the ICTV website (see King 2012 ICTV Discussions) opposing the proposed new definition of virus species. Subsequently, King et al. responded on the ICTV website with a 4-page, polemical document in which they claimed that the ICTV definition of virus species used since 1991 was based on specious reasoning and on meaningless terms such as polythetic class, replicating lineage and ecological niche. All the arguments and counterarguments are available on the ICTV website (King 2012 ICTV 
Discussions) and the shortcomings of the proposed new definition were described in detail by a group of six ICTV Life Members and eight other senior virologists (Van Regenmortel et al. 2013). These shortcomings are summarized below.

(1) In the ICTV forum (King 2012), the proposers of the new species definition repeated the same mistake as Gibbs \& Gibbs (2006) when they claimed that since a species corresponds to a replicating lineage, it cannot be a polythetic class because all its members must have inherited one or more properties from a common ancestor which makes the class a monothetic one. However, a variable distribution of properties in the members of the class together with the absence of a single common defining property in all of them is what defines a polythetic class. This combination of properties does not itself constitute a single common property shared by all the members of the class since it is a characteristic of the class rather than a property of its members. A variable distribution of properties in a class is not itself a single common property of all the members of the class, since if this were the case, it would turn every polythetic class into a monothetic one (Van Regenmortel et al. 2013).

Every membership condition determines a class but since a class is not a concrete object, it cannot itself figure as a candidate for membership of the class. Virus classes only admit viruses as members but cannot admit themselves as members. Membership of classes can thus be determined by one or many membership conditions, except one which is non-self membership (Quine \& Ullian 1978: 44; Quine 1990: 94). The adjective 'long', for instance, denotes the class of long things but since it is not a long adjective, it is a nonself denoting property of the class. If one fails to appreciate that the non-self membership condition does not determine the class, one lands with the well-known Russell paradox of the barber which can be stated as follows. If one assumes that a village barber shaves all and only those men in the village who do not shave themselves, one lands with a contradiction since the barber will need to shave himself only if he does not do so (Baldwin \& Lessmann 1998). The paradox is resolved only when it is realized that there is no such barber (Quine 1990: 146). As clearly stated by Quine (1990: 227): "When we say of some class that it is not a member of itself we do not thereby assign it to a class of all non-self members; for that class, if it existed, would have to be a member of itself if and only if it was not. Similarly when we say of some property that it is not a property of itself we do not thereby ascribe a property to it". The non-self membership condition also excludes the possibility that the class of all polythetic classes could form a monothetic class that would have viruses (instead of classes) as its members.

(2) The preposterous claim was also made by the proposers of the new definition (King 2012) that the term 'class' should only be used to denote a category in the classification hierarchy, i.e. the one situated above the category order and below the category phylum, although such a category is not used in virus classification. They seem to be unaware that the conceptual construct of class is universally used in taxonomy because it makes it possible to establish a link between the abstract class and the concrete organisms or viruses that are members of a class. They object to a virus species being called a polythetic class and propose instead to define a species as a 'group' of viruses. However, a group of viruses is only a collection of viral objects that are linked to the group by the part-whole relation and such a terminology contradicts the logic of classes used in taxonomy which uses only the relations of class membership and class inclusion for building up a classification (see section 3).

(3) The proposers of the new definition (King 2012) also dismissed the glaring case of the 288 begomovirus species that were created by ignoring the polythetic principle and accepting that species could be established on the basis of a single arbitrary criterion, namely less than $89 \%$ pairwise sequence identity in the viral DNA-A genome (Fauquet et al. 2003) .Virus classification by Pairwise Sequence Comparison (PASC) of viral genome sequences has been used increasingly in recent years (Bao et al. 2010). It produces plots of the frequency distribution of pair-wise identity percentages from all available genome sequences of viruses in a family which show multimodal distributions of peaks that can tentatively be attributed to clusters of sequences that could correspond to groups of serotypes, strains, species, genera or subfamilies (Van Regenmortel 2007). In the case of the begomoviruses in the Geminiviridae family, a cut-off point of less than $89 \%$ sequence identity in the DNA-A genome was chosen as sole criterion for separating strains from species and this led to the creation of 288 different species in the absence of any biological evidence that such taxa 
corresponded to distinguishable, stable entities that would justify the label 'species' rather than the label 'strain'. It was argued (King 2012) that the sole use of the $89 \%$ cut-off point was not an arbitrary decision because it was based on quantitative genome data. They refused to admit that choosing a lower percentage cut-off point in the PASC peaks could have produced a smaller, more reasonable number of begomovirus species. Many of the so-called 288 different 'species' consist of viruses that infect the same host (cotton or tomato) and produce very similar disease symptoms, and had to be given different names by including the geographical location of the first isolation of the virus. This produced a long list of species names such as Tomato leaf curl Comoros virus, Tomato leaf curl Guangxi virus, Tomato leaf curl Hsinchu virus, Tomato leaf curl New Delhi, etc., which could have been considered strains of the same species if a lower threshold demarcation percentage for creating species had been chosen (Van Regenmortel 2011). The allocation of different begomoviruses to the category strain or variant is equally arbitrary (Fauquet et al. 2008) while attributing a peak to so-called 'virus isolates' is in fact meaningless since isolates can refer to any virus that is being studied experimentally, which could be a member of a strain, species or genus (Van Regenmortel 2007).

Recently, the criteria for distinguishing begomovirus species and strains on the basis of pairwise sequence comparisons were revised, which led to the recognition of even more species, i.e. 307 instead of 288 (Brown et al. 2015). No major peaks or valleys were present in the pairwise distance distribution plot and thresholds of less than $91 \%$ for species and less than $94 \%$ for strains were nevertheless used for classifying begomoviruses. This led, for instance, to the recognition of 42 different Tomato leaf curl virus species mainly on the basis of the geographical location of viruses. Although the authors claimed that this number of species reflects the biological differences between them (Brown et al 2015), they did not elaborate on how these 42 species actually differed biologically from each other, which could have justified giving them the label 'species' . A remarkable natural genetic variabilty is indeed present in the Begomovirus genus which seems to be linked to recent, unprecedented world-wide infestations of whiteflies belonging to the Bemisia tabaci species complex (Brown et al 2015). However, the exorbitant number of proposed begomovirus species may be due more to the ability of quickly sequencing large numbers of similar genomes than to the presence of significant biological differences between closely related, individual species. In the genus Mastrevirus in the same Geminiviridae family, a more appropriate cut-off point of $75 \%$ sequence identity in DNA-A sequences was used which led to the creation of only 12 separate species (Fauquet \& Stanley 2005). In the genus Curtovirus of the same family, more than half of the species that had been established previously using a species demarcation threshold of $89 \%$ ceased to exist when the threshold was reduced to $77 \%$ (Varsani et al. 2014). It should also be pointed out that relying on a single percentage of genome pairwise identity for assigning many virus isolates to one species is of little use for deciding how isolates with a lower percentage identity can be assigned to separate species. The three virus species that were established in the Curtovirus genus on the basis of their different host species were labeled as monophyletic (in accordance with the new ICTV species definition) although using the host as criterion is a strange way of assessing monophyly (Varsani et al. 2014). Establishing valid demarcation criteria in the family Geminiviridae is particularly difficult because of the frequent occurrence of recombination events between different geminiviruses (Padidam et al. 1999; Ball 2005).

All the above-mentioned objections to the new species definition were ignored by the ICTV EC and the proposal was ratified using a fast-track approval process which considerably reduced the time available for posting further objections and comments on the ICTV website. The ballot return rate of votes was $41 \%$ of those entitled to vote (consisting of about two dozen ICTV EC and subcommittee members, a dozen ICTV Life members and more than 40 national representatives elected by each microbiological society of the IUMS, not necessarily on the basis of taxonomic competence). The results of the ballot was 45 in favour, 21 against and 2 abstentions (Adams et al. 2013). According to Van Regenmortel et al. (2013), the new species definition is in no way superior, and in many ways inferior, to the earlier ICTV definition; by removing the polythetic principle, it certainly will not make it easier for virologists to establish or recognize new species in the future. 


\section{Non-Latinized binomial names for virus species}

The assignment of names to virus taxa is the responsibility of the ICTV which is a committee of the Virology Division of the International Union of Microbiological Societies (IUMS). The names of virus genera, subfamilies, families and orders have for many years been written in italics with a capital letter which is a different typography from that advocated for such taxa by the Biological Code of Nomenclature (Van Regenmortel 2001). The unique position of viruses in biology is one of the reasons why the traditions of the International Code of Zoological Nomenclature (Anonymous 1999), the International Code of Nomenclature of Bacteria (Lapage et al. 1992) and the International Code of Botanical Nomenclature (McNeill et al. 2012) are not followed by virologists. The ICTV as the voice of the international community of virologists has always followed its own rules and Code and tends not to follow traditions present in the rest of biology such as the use of Latin names (Matthews 1983) or the formation of binomial species names using the order genusname-first/species identifier-second, instead of the reversed order (species-first/genus-second) introduced in virology 50 years ago (Fenner 1976). ICTV activities are governed by Statutes and by the International Code of Virus Classification and Nomenclature (ICVCN). The most recent version of the Code was published in the $9^{\text {th }}$ ICTV Report (King et al. 2012b). Between successive Reports, ratified changes to the Code and to virus classification and nomenclature are brought to the attention of virologists in the 'Virology Division News' (VDN) columns of Archives of Virology, the official journal of the Virology Division of IUMS (Mayo \& Van Regenmortel 2000; Kuhn et al. 2015).

The respective names of virus taxa have the following endings: -virus for genera, -virinae for subfamilies, -viridae for families and -virales for orders (Fauquet 2010). It has been suggested that unofficial vernacular names for the members of these four taxa could be introduced using taxon-specific suffixes (Vetten \& Haenni 2006). The suffixes are '-virad' for members of an order, '-virid' for members of a family, '-virin' for members of a subfamily and '-genus' for members of a genus. This is useful, for instance, when a genus name such as Parvovirus served as a basis for coining the family (Parvoviridae) and subfamily (Parvovirinae) names. When referring to a parvovirus, it is not clear if one is thinking of a member of the family, subfamily or genus, whereas referring to a parvovirid, parvovirin or parvovirus removes any ambiguity.

Regarding species names, I had proposed to the ICTV Executive Committee (EC) in 1998 that two alternative changes could be introduced in species names. The one proposal was to adopt the common English names of viruses as species names but to italicize them with the initial letter capitalized in order to provide a visible sign that species correspond to taxonomic classes, just like italicized genera and families. The other proposal was to adopt non-Latinized binomial names (NLBNs) which had been used unofficially for many years in plant virology papers and books (Matthews 1971; Brunt et al. 1990; Albouy \& Devergne 1998; Bos $1999 a$ ) and in the indices of earlier ICTV Reports (Fenner 1976; Matthews 1979, 1982). In the Fifth ICTV Report (Francki et al. 1991), NLBNs were retained only for indexing plant viruses and in the Sixth Report (Murphy et al. 1995) they were dropped altogether because some animal virologists were opposed to their use. One argument against the introduction of binomial species names was that long established virus names would have to be abandoned. However, this was not the case since original names of viruses would be retained and the new names concerned only virus species for which names did not yet exist.

It was proposed in 1998 that NLBNs for species would be italicized with a capital initial and would be obtained by replacing the terminal word 'virus' occurring in all common English virus names with the genus name to which the virus belongs, which also ends in -virus. Such a system would not require the creation of completely new names for thousands of virus species which would be the case if Latin binomial names were introduced (Bos 1999b, 2000; Agut 2002; Van Regenmortel 2000, 2007).

In 1998, the majority of the members of the ICTV EC, who were not plant virologists, adopted the first proposal in spite of the fact that NLBNs could have been immediately endorsed for more than $90 \%$ of the 1550 virus species recognized at the time (Van Regenmortel \& Fauquet 2002). As a result of this decision, measles virus became officially a member of the species Measles virus (Mayo \& Horzinek 1998). Within a 
few years after the adoption of species names which differed from virus names only by typography, it became clear that many virologists found it difficult to use these names correctly because they constantly had to decide whether they wanted to refer to the virus or to the taxonomic species class, a distinction that many of them found difficult to make (Drebot et al. 2002; Calisher \& Mahy 2003; Van Regenmortel 2007; Kuhn \& Jahrling 2010).Virologists would, for instance, frequently write that Measles virus or Cucumber mosaic virus had been isolated, transmitted to a host or sequenced although species, being taxonomic constructs of the mind, cannot have hosts, vectors nor sequences. Such logically incorrect sentences are common in biology because the majority of animals, plants and microorganisms have no vernacular names in English or other languages. Scientists will therefore write that Escherichia coli (i.e. the species) has been infected by a virus, as if a taxonomic concept could be infected (Calisher \& Van Regenmortel 2009). In virology, such statements are easily avoided since all viruses have vernacular names and the name of the virus, instead of the species, can always be used to refer to the infectious agent. It has been suggested that introducing binomial species names should be postponed until laboratory virologists had fully grasped the non-identity of conceptual species and concrete viruses (Kuhn \& Jahrling 2010). This may well be counterproductive since it is actually by using species NLBNs that clearly differ from virus names that virologists would demonstrate in their writing that they understood the distinction. How else would one know that they had grasped it?

Virologists have come to realize that the use of species NLBNs has the advantage that because binomial names in biology are always associated with taxonomic entities, this makes it easier for them to recognize that binomial names are the names of virus species rather than of viruses (Bos 2002). It is also evident that NLBNs provide useful additional information on the properties of the viruses, deduced from membership in a genus, which was the reason Fenner started to use binomial names already in 1976. It is immediately obvious that hepatitis A, B and C are very different infectious agents belonging to separate genera when their species names are Hepatitis $A$ hepatovirus, Hepatitis $B$ orthohepadnavirus and Hepatitis $C$ hepacivirus respectively (Van Regenmortel \& Fauquet 2002).

In 2002, efforts were made to canvass the opinion of virologists who attended an international Virology conference in Paris regarding their acceptance of species NLBNs. The results of two ballots showed that a significant majority (80-85\%) of the 250 virologists who expressed an opinion were in favour of binomial names for species (Mayo 2002; Van Regenmortel \& Fauquet 2002). In 2004, half the members of the ICTV EC no longer objected to such names although the EC had found it difficult to canvass the opinion of the more than 80 ICTV Study Groups because only a few of them made their views known (Ball \& Mayo 2004).

As it became obvious that NLBNs were superior to the official species names, a proposal was made to generalize the use of such binomial names for all virus species (Van Regenmortel et al. 2010). However, the ICTV EC decided that the use of such species names should not be mandatory but that it should be left to Study Groups to initiate formal proposals if they wished to introduce binomial names for certain virus families. Jens Kuhn who is a member of several Study Groups as well as the editor responsible for the 'Virology Division News' section of Archives of Virology (the official journal of the Virology Division of IUMS) has been very active in introducing binomial species names in several families such as the Arenaviridae, Bornaviridae, Filoviridae, Nyamiviridae, Rhabdoviridae, Bunyaviridae and Paramyxoviridae (Bukreyev et al. 2014; Kuhn et al. 2015). Paradoxically, some plant virologists who had strongly criticized the ICTV in the past for not ratifying NLBNs for all virus species (Gibbs 2000) have in the meantime become adepts of Latinized, binomial species names and believe that viruses are organisms (Gibbs 2003). It is sometimes argued that viruses are living microorganisms because they share with certain parasitic organisms such as Mycoplasma genitalium the property of being obligate parasites. However, the dependency of viral genes on their cellular hosts is a type of 'genetic parasitism' that is totally different from the dependency shown, for instance, by bacteria that colonize the gut of certain animals. The claim that obligate parasitism on its own is a sufficient criterion for establishing that an entity is alive goes against the well-established consensus that living organisms possess an autonomy and many metabolic and functional capacities that are never found in viruses nor in any non-living matter (Mahner \& Bunge 1997: 141-146; Van Regenmortel 2010a, 2016). 


\section{Discussion}

Sections 4-8 of this review followed a chronological presentation of recent developments in viral taxonomy which revealed that the field has been plagued by an uninterrupted series of conflicting views, heated disagreements and acrimonious controversies that may seem to some to be out of place in a scientific debate. The reason, of course, is that the subject of virus taxonomy and nomenclature lies at the interface between virological science and areas of philosophy such as logic, ontology and epistemology which unfortunately are rarely taught in university curricula followed by science students (Blachowicz 2009). Richard Feynman quipped that "philosophy of science is about as useful to scientists as ornithology is to birds" while Imre Lakatos lamented that: "most scientists tend to understand little more about science than fish about hydrodynamics" (Nola \& Sankey 2007: 2). It is nevertheless regrettable that an instructive and clarifying book such as the Foundations of Biophilosophy (Mahner \& Bunge 1997) does not feature more often as compulsory reading in postgraduate courses offered to biology students.

Philosophy abounds with contradictory views and interpretations regarding the nature of biological phenomena and the ongoing debate about species being classes or individuals discussed (see section 3) is clearly a philosophical issue. What is more unexpected is that plant virologists were much more reluctant than animal virologists to accept virus species as useful classes in viral taxonomy and that they claimed that establishing such taxa 'logically' entailed that they would be given Latin names, which they strongly opposed (Matthews 1983). The appeal to logic in such debates (Bos 1999b) is indeed astonishing since Latinization is only a matter of linguistic convention and tradition in biology and most virologists do not view viruses as living organisms (Van Regenmortel 2016) that should be classified according to the rules of the proposed Biocode (Greuter et al. 2011). When virus species names eventually became italicized English binomial names instead of italicized Latin binomial names, Gibbs $(2000,2003)$ who claims that "plant virologists have a greater call on nomenclature than most working animal virologists", tried to downplay the contemporary primacy of English in virological communications by stating that Latin, anyway, had never been the language of communication between scientists, a claim that is patently untrue (Van Regenmortel 2003). It cannot be denied that English has now replaced Latin as the predominant communication language used by scientists. The major journals and reference books in Virology are written in English and virologists, irrespectively of their mother tongue, are familiar with English virus names. Inventing thousands of new Latin binomial names for virus species is unlikely to be a welcome alternative.

Claims that the ICTV is leading virus nomenclature into chaos have also been repeatedly refuted (Van Regenmortel et al. 2000) and the derogatory tone that is sometimes used in such attacks has been deplored. There is indeed no ground for claiming that ICTV is breaking its own rules since it only amends them following due process, nor for asserting that ICTV has become isolated from its broader electorate of virologists and no longer represents their interests (Gibbs 2003). ICTV activities are increasingly displayed in the VDN columns (Mayo \& Van Regenmortel 2000; Kuhn et al. 2015; Radoshitzky et al. 2015) and the advice extended by Gibbs that all virologists should ignore the ICTV is itself a neat recipe for chaos and is best dismissed as provocation (Van Regenmortel et al. 2000). The ICTV has also been criticized for not providing extensive descriptions of individual viruses in their ICTV Reports. This task was supposed to be fulfilled by the Universal Virus Database (Anonymous 2002). It is unfortunate that this project has now been abandoned (Buchen-Osmond et al. 2000; Ball 2005).

ICTV is a democratic organization and it has refused to implement a mandatory system of NLBNs for all virus species, partly because of the past opposition of many animal virologists. These virologists, incidentally, dismissed the fact that the famous animal virologist Frank Fenner (1976) had been the first person to use the system. As discussed in section 8 , it is not always clear what sort of democratic process would satisfy the ICTV, or for that matter its critics, and it can only be hoped that virologists will be more inclined in the future to engage in taxonomic debates than they did in the past (Matthews 1983). Few virologists express an opinion on taxonomic issues with the result that minority views expressed by a few vocal individuals are often heard disproportionally. 
The latest official ICTV definition of virus taxon which masquerades as a definition of virus species and does not accept that classes are indisputable constituents of any classification scheme, testifies to the need for virologists not to follow the desperate call that they should leave taxonomy alone (Calisher \& Mahy 2003). Frederick Murphy, a Life Member and past President of ICTV, in his contribution to the ICTV forum on the pros and cons of the new ICTV species definition (King 2012), suggested that a one day international meeting should be convened to hammer out controversial taxonomic issues that cannot be resolved in the few minutes usually available during a Virology Congress.

The following assertions could be discussed at such a meeting: (1) classification deals with classes, taxonomy deals with taxa; (2) virus taxa are conceptual classes that have viruses as their members and are not constituted of groups of real viruses; (3) virus species cannot be described and can only be defined by listing certain species-defining properties of their members; (4) a nucleotide motif is a chemical part of a viral genome but is not a species defining property that could be used to establish new virus species; (5) virus isolates can be assigned to previously recognized virus species by using diagnostic criteria such as nucleotide motifs although these are not species-defining properties; (6) the official 2013 ICTV definition of species is not appropriate because it applies equally to virus genera; (7) a virus classification based only on nucleotide sequences is a classification of genome sequences and not of viruses; (8) since phenotypic and biological properties of a virus cannot be deduced from its genome sequence, species demarcation is not feasible by considering only nucleotide sequences; this is the reason why virus species were previously defined as polythetic or cluster classes since this required that phenotypic and biological properties of viruses should also be considered in species demarcation; (9) the variable distribution of properties that characterises a cluster class is not itself a single common property of all the members of the class, since this would lead to the paradox that a polythetic class is a monothetic one.

\section{References}

Adams, M. J., Lefkowitz, E. J., King, A. M. Q. \& Carstens, E. B. (2013) Recently agreed changes to the International Code of Virus Classification and Nomenclature. Archives of Virology, 158: 2633-2639.

Anonymous [International Commission on Zoological Nomenclature] (1999) International code of zoological nomenclature. Fourth edition. London (International Trust for zoological Nomenclature). $<\mathrm{http}$ ://www.iczn.org/> [accessed 6 November 2015].

Anonymous [International Committee on Taxonomy of Viruses] (2002) The Universal Virus Database of the International Committee on Taxonomy of Viruses. <http://web.archive.org/web/20070611143548/ http:// phene.cpmc.columbia.edu/index.htm $>$ [accessed 18 Feburary 2016].

Albouy, J. \& Devergne, J. C. (1998) Maladies à virus des plantes ornementales. Paris (Éditions de l'INRA).

Agut, H. (2002) Back to Latin and tradition: a proposal for an official nomenclature of virus species. Archives of Virology, 147: 1465-1470.

Baldwin, J. T. \& Lessmann, O. (1998) What is Russell's paradox? Scientific American, 17 August 1998.

Ball, L. A. (2005) The universal taxonomy of viruses in theory and practice. In: C. M. Fauquet, M. A. Mayo, J. Maniloff, U. Desselberger \& L. A. Ball (ed.), Virus taxonomy. Eight Report of the International Committee on Taxonomy of Viruses. Amsterdam (Elsevier Academic Press): 3-8. <http://dx.doi.org/10.1016/b978-0-12-249951-7.50003-1>

Ball, L. A. \& Mayo, M. A. (2004) Report from the $33^{\text {rd }}$ Meeting of the ICTV executive committee. Archives of Virology, 149: 1259-1263. <http://dx.doi.org/10.1007/s00705-004-0338-3>

Bao, Y., Kapustin, Y. \& Tatusova, T. (2010) Virus classification by Pairwise Sequence Comparison (PASC). In: M. H. V. Van Regenmortel \& B. Mahy (ed.), Desk encyclopedia of general virology, Oxford (Academic Press, Elsevier): 95-100.

Beckner, M. (1959) The biological way of thought. New York (Columbia University Press).

Bernier, R. (1984) The species as an individual: facing essentialism. Systematic Zoology, 33: 460-469. <http:// dx.doi.org/10.2307/2413097>

Blachowicz, J. (2009) How science textbooks treat scientific method: a philosopher's perspective. British Journal for the Philosophy of Science, 60: 303-344. <http://dx.doi.org/10.1093/bjps/axp011> 
Bos, L. (1999a) Plant viruses, unique and intriging pathogens - A textbook of plant virology. Leiden (Backhuys Publishers).

Bos, L. (1999b) The naming of viruses: an urgent call to order. Archives of Virology, 144: 631-636. <http://dx.doi.org/ $10.1007 / \mathrm{s} 007050050532>$

Bos, L. (2000) Structure and typography of virus names. Archives of Virology, 145: 429-432. <http://dx.doi.org/ $10.1007 / \mathrm{s} 007050050035>$

Bos, L. (2002) International naming of viruses. A digest of recent developments. Archives of Virology, 147: 1471-1477. $<$ http://dx.doi.org/10.1007/s007050200044>

Bos, L. (2003) Virus nomenclature; continuing topicality. Archives of Virology, 148: 1235-1246. <http://dx.doi.org/ $10.1007 / \mathrm{s} 00705-003-0129-2>$

Brown, J. K., Zerbini, F. M., Navas-Castillo, J., Morlones, E., Ramos-Sobrinho, R., Silva, J. C. F., Fiallo-Olivé, E., Briddon, R. W., Fernandez-Zepeda, C., Idris, A., Malathi,V. G., Martin, D. P., Rivera-Bustamante, R., Ueda, S. \& Varsani, A. (2015) Revision of Begomovirus taxonomy based on pairwise sequence comparisons. Archives of Virology, 160: 1593-1619. <http: dx.doi.org/10.1007/s00705-015-2398-y>

Brunt, A., Crabtree, K. \& Gibbs, A. (1990) Viruses of tropical plants. Wallingford (CAB International).

Buchen-Osmond, C., Blaine, L. \& Horzinek, M. C. (2000) The Universal Virus Database of ICTV (ICTVdB). In: M. H. V. Van Regenmortel, C. M. Fauquet, D. H. L. Bishop, E. B. Carstens, M. K. Estes, S. M., Lemon, J. Maniloff, M. A. Mayo, D. J. McGeoch, C. R. Pringle \& R. B. Wickner (ed.), The Seventh Report of the International Committee on Taxonomy of Viruses, Academic Press, Elsevier Science \& Technology Books.

Buck, R. C. \& Hull, D. L. (1966) The logical structure of the Linnaean hierarchy. Systematic Zoology, 15: 97-111. $<\mathrm{http}: / /$ dx.doi.org/10.2307/2411628>

Bukreyev, A. A., Chandran, K., Dolnik, O., Dye, J. M., Ebihara, H., Leroy, E. M., Mühlberger, E., Netesov, S. V., Patterson, J. L., Paweska, J. T., Saphire, E. O., Smither, S. J., Takada, A., Towner, J. S., Volchkov, V. E., Warren, T. K. \& Kuhn, J. H. (2014) Discussions and decisions of the 2012-2014 International Committee on Taxonomy of Viruses (ICTV) Filoviridae Study Group, January 2012-June 2013. Archives of Virology, 159: 821-830. <http:// dx.doi.org/10.1007/s00705-013-1846-9>

Calisher, C. H., Horzinek, M., Mayo, M. A., Ackermann, H. W. \& Maniloff, J. (1995) Sequence analyses and a unifying system of virus taxonomy: consensus via consent. Archives of Virology, 140: 2093-2099. <http://dx.doi.org/ 10.1007/BF01322696>

Calisher, C. H. \& Mahy, B. M. J. (2003) Taxonomy: get it right or leave it alone. The American Society of tropical Medicine \& Hygiene, 68: 505-506.

Calisher, C. H. \& Van Regenmortel, M. H. V. (2009) Should all other biologists follow the lead of virologists and stop italicizing the names of living organisms? A proposal. Zootaxa, 2113: 63-68.

Claridge, M. F. (2010) Species are real biological entities. In: F. J. Ayala \& R. Arp (ed.), Contemporary debates in philosophy of biology, Chichester, UK (Wiley-Blackwell): 91-109.

Colwell, R. K. (1992) Niche: a bifurcation in the conceptual lineage of the term. In: E. F. Keller \& E. A. Lloyd (ed.), Keywords in evolutionary biology, Cambridge, Mass. (Harvard University Press): 241-248.

De Queiroz, K. \& Donoghue, M. J. (1988) Phylogenetic systematics and the species problem. Cladistics, 4: 317-338. $<\mathrm{http}: / /$ dx.doi.org/10.1111/j.1096-0031.1988.tb00518.x>

Dekker, E. L., Dore, I., Porta, C. \& Van Regenmortel, M. H. V. (1997) Conformational specificity of monoclonal antibodies used in the diagnosis of tomato mosaic virus. Archives of Virology, 95: 191-203.

Drebot, M. A., Henchal, E., Hjelle, B., Le Duc, J. W., Repik, P. M., Roehrig, J. T., Schmaljohn, C. S., Shope, R. E., Tesh, R. B., Weaver, S. C. \& Calisher, C. H. (2002) Improved clarity of meaning from the use of both formal species names and common (vernacular) virus names in virological literature. Archives of Virology, 147: 2465-2471. <http://dx.doi.org/10.1007/s00705-002-0938-8>

Dubois, A. (2011) Species and 'strange species' in zoology: do we need a 'unified concept of species'. Comptes rendus Palevol., 10: 77-94. <http://dx.doi.org/10.1016/j.crpv.2011.01.002>

Ebach, M. C. \& Holdrege, C. (2005) More taxonomy, not DNA barcoding, Bioscience, 55: 822-823. <http://dx.doi.org/ 10.1641/0006-3568(2005)055[0823:MTNDB]2.0.CO;2>

Ereshefsky, M. (2009) Darwin's solution to the species problem. Synthese. $<$ http://dx.doi.org/10.1007/s11229-0099538-4>

Fauquet, C. M. (2010) Taxonomy, classification and nomenclature of viruses. In: B. W. J. Mahy \& M. H. V. Van Regenmortel (ed.), Desk encyclopedia of general virology, San Diego (Elsevier): 80-95.

Fauquet, C. M., Bisaro, D. M., Briddon, R. W., Brown, J. K., Harrison, B. D., Rybicki, E. P., Stenger, D. C. \& Stanley, J. (Study Group Chair) (2003) Virology Division News: revision of taxonomic criteria for species demarcation in the 
family Geminiviridae, and an updated list of begomovirus species. Archives of Virology, $148: 405-421 .<\mathrm{http}: / /$ dx.doi.org/10.1007/s00705-002-0957-5>

Fauquet, C. M., Briddo, R. W., Brown, J. K., Moriones, E., Stanley, J., Zerbini, M. \& Zhou, X. (2008) Geminivirus strain demarcation and nomenclature. Archives of Virology, 153: 783-821. <http://dx.doi.org/10.1007/s00705-008-0037-6>

Fauquet, C. M. \& Stanley, J. (2005) Revising the way we conceive and name viruses below the species level: a review of geminivirus taxonomy calls for new standardized isolate descriptors. Archives of Virology, 150: 2151-2179.

Fenner, F. (1976) The classification and nomenclature of viruses. Second Report of the International Committee on Taxonomy of Viruses. Intervirology, 7: 1-115. <http://dx.doi.org/10.1159/000149938>

Francki, R. I. B., Fauquet, C. M., Knudson, D. L. \& Brown, F. (1991) Fifth Report of the International Committee on Taxonomy of Viruses. Archives of Virology, Supplementa, 2: 450. <http://dx.doi.org/10.1007/978-3-7091-9163-7>

Fristrup, K. (1992) Character: current usages. In: E. F. Keller \& E. A. Lloyd (ed.), Keywords in evolutionary biology, Cambridge, MA (Harvard University Press): 45-51.

Ghiselin, M. T. (1974) A radical solution to the species problem. Systematic Zoology, 23: 536-544. <http://dx.doi.org/ $10.2307 / 2412471>$

Gibbs, A. J. (2000) Virus nomenclature descending into chaos. Archives of Virology, 145: 1505-1507. <http:// dx.doi.org/10.1007/s007050070108>

Gibbs, A. J. (2003) Virus nomenclature: where next ? Archives of Virology, 148: 1645-1653. <http://dx.doi.org/10.1007/ s00705-003-0150-5>

Gibbs, A. J., Armstrong, J. S. \& Gibbs, M. J. (2004) A type of nucleotide motif that distinguishes tobamovirus species more efficiently than nucleotide signatures. Archives of Virology, 149: 1941-1954.

Gibbs, A. J. \& Gibbs, M. J. (2006) A broader definition of the 'virus species'. Archives of Virology, 151: $1419-1422$. $<$ http://dx.doi.org/10.1007/s00705-006-0775-2>

Gibbs, A. J. \& Harrison, B. (1976) Plant virology. The principles. London (Edward Arnold).

Gorbalenya, A. E. (2010) Phylogeny of viruses. In: B. W. J. Mahy \& M. H. V. Van Regenmortel (ed.), Desk encyclopedia of general virology, San Diego (Elsevier): 66-69.

Greuter, W., Garrity, G., Hawksworth, D. L., Jahn, R., Kirkn P. M., Knapp, S., McNeill, J., Michel, E., Patterson, D. J., Pyle, R. \& Tindall, B. R. J. (2011) Draft BioCode (2011). Principles and Rules regulating the naming of organisms. New draft, revised in November 2010. Bionomina, 3: 26-44. <http://dx.doi.org/10.11646/bionomina.3.1.3>

Hebert, P. D. N. \& Gregory, T. R. (2005) The promise of DNA barcoding for taxonomy. Systematic Biology, 54: 852-859. <http://dx.doi.org/10.1080/10635150500354886>

Hull, D. L. (1976) Are species really individuals? Systematic Zoology, 25: 174-191. <http://dx.doi.org/10.2307/ $2412744>$

Hull, D. L. (1988) Science as a process. Chicago (The University of Chicago Press). <http://dx.doi.org/10.7208/chicago/ 9780226360492.001.0001>

Inglis, W. G. (1991) Characters: the central mystery of taxonomy and systematics. Biological Journal of the Linnean Society, 44: 121-139. <http://dx.doi.org/10.1111/j.1095-8312.1991.tb00611.x>

King, A. (2012) Comments to proposed modification to code rule 3.21 (defining virus species). ICTV Discussions. $<\mathrm{http}$ //talk.ictvonline.org/discussions/ictv1/f/63/t/3930.aspx/> [Accessed on 6 November 2015].

King, A., Adams, M., Lefkowitz, E. \& Carstens, E. (2012a) ICTV Proposal 2011.002sg. In: 2011.002auG.A.v9.statute_and_code_changes.pdf (page 15)<http://talk.ictvonline.org/files/ictv_official_taxonomy_updates _since_the_8th_report $/ \mathrm{m} /$ general-2008/4444.aspx $>$ [Accessed on 6 November 2015].

King, A., Lefkowitz, E., Adams, M. J. \& Carstens, E. (ed.) (2012b) Virus taxonomy. Ninth Report of the International Committee on Taxonomy of Viruses. Elsevier Academic Press. ISBN: 978-0-12-384684-6.

Kingsbury, D. W. (1985) Species classification problems in virus taxonomy. Intervirology, 24: 62-70. <http:// dx.doi.org/10.1159/000149621>

Krupovic, M. \& Bamford, D. H. (2010) Order to the viral universe. Journal of Virology, 84: 12476-12479. <http:// dx.doi.org/10.1128/JVI.01489-10>

Krupovic, M. \& Bamford, D. H. (2011) Double-stranded DNA viruses: 20 families and only five different architectural principles for virus assembly. Current Opinion in Virology, 1: 118-124. <http://dx.doi.org/10.1016/ j.coviro.2011.06.001>

Kuhn, J. H., Dürrwald, R., Bao, Y., Briese, T., Carbone, K., Clawson, A. N., de Risi, J. L., Garten, W., Jahrling, P. B., Kolodziejek, J., Rubbenstroth, D., Schwemmle, M., Stenglein, M., Tomonaga, K., Weissenböck, H. \& Nowotny, N. (2015) Taxonomic reorganization of the family Bornaviridae. Archives of Virology, 160: 621-632. <http:// dx.doi.org/10.1007/s00705-014-2276-z> 
Kuhn, J. H. \& Jahrling, P. B. (2010) Clarification and guidance on the proper usage of virus and virus species names. Archives of Virology, 145: 445-453. <http://dx.doi.org/10.1007/s00705-010-0600-9>

Lapage, S. P., Sneath, P. H. A., Lessel, E. F., Skerman, V. B. D., Seeliger, H. P. R. \& Clark, W. A. (ed.) (1992) International code of nomenclature of bacteria. Washington, DC (ASM Press).

Lewontin, R. C. (1992) Genotype and phenotype. In: E. Fox Keller \& E. A. Lloyd (ed.), Keywords in evolutionary biology, Cambridge (Harvard University Press): 137-144.

Mahner, M. \& Bunge, M. (1997) Foundations of biophilosophy. Berlin (Springer-Verlag). <http://dx.doi.org/10.1007/ 978-3-662-03368-5>

Matthews, R. E. F. (1971) Plant virology. San Diego (Academic Press).

Matthews, R. E. F. (1979) Classification and nomenclature. Third Report of the International Committee on Taxonomy of Viruses. Intervirology, 7: 1-115.

Matthews, R. E. F. (1982) Classification and nomenclature of viruses. Fourth Report of the International Committee on Taxonomy of Viruses. Intervirology, 17: 1-200. <http://dx.doi.org/10.1159/000149278>

Matthews, R. E. F. (1983) The history of viral taxonomy. In: R. E. F. Matthews (ed.), A critical appraisal of viral taxonomy, Boca Raton, Florida (CRC Press): 1-35.

Matthews, R .E. F. (1985a) Viral taxonomy. Microbiological Sciences, 2: 74-75.

Matthews, R. E. F. (1985b) Viral taxonomy for the non-virologist. Annual Review of Microbiology, 39: 451-474. <http:/ /dx.doi.org/10.1146/annurev.mi.39.100185.002315>

Mayo, M. A. (2002) ICTV at the Paris ICV: results of the plenary session and the binomial ballot. Archives of Virology, 147: 2254-2260. $<\mathrm{http} / / \mathrm{dx}$.doi.org/10.1007/s007050200052>

Mayo, M. A. \& Horzinek, M. C. (1998) A revised version of the International Code of Virus Classification and Nomenclature. Archives of Virology, 143: 1645-1654. <http://dx.doi.org/10.1007/s007050050406>

Mayo, M. A. \& Van Regenmortel, M. H. V. (2000) ICTV and the Virology Division News. Archives of Virology, 145: 1985-1988. <http://dx.doi.org/10.1007/s007050070071>

Mayr, E. (1970) Populations, species and evolution. Cambridge, Mass. (Harvard University Press).

Mayr, E. (1982) The growth of biological thought. Diversity, evolution and inheritance. Cambridge, MA (Harvard University Press).

McNeill, J., Barrie, F. R., Buck, W. R., Demoulin, V., Greuter, W., Hawksworth, D. L., Herendeen, P. S., Knapp, S., Marhold, K., Prado, J., Prud'homme Van Reine, W. F., Smith, G. F. \& Wiersema, J. H. (ed.) (2012) International code of nomenclature for algae, fungi, and plants (Melbourne Code). Koeltz Scientific Books. < http://www.iapttaxon.org/nomen/main.php/> [Accessed on 6 November 2015].

Milne, R. G. (1984) The species problem in plant virology. Microbiological Sciences, 1: 113-122.

Mishler, B. D. (2010) Species are not uniquely real biological entities. In: F. J. Ayala \& R. Arp (ed.), Contemporary debates in philosophy of Biology, Chichester, UK (Wiley-Blackwell): 110-122.

Moss, L. (2001) Deconstructing the gene and reconstructing molecular developmental systems. In: S. Oyama, P. Griffiths \& R. Gray (ed.), Cycles of contigency - Developmental systems and evolution, Cambridge (MIT Press): 85-97.

Moss, L. (2003) What genes can't do. Cambridge, Massachusetts (MIT Press).

Murphy, F. A., Fauquet, C. M., Bishop, D. H. L., Ghabrial, S. A., Jarvis, A. W., Martelli, G. P., Mayo, M. A. \& Summers, M. D. (ed.) (1995) Virus taxonomy. Sixth Report of the International Committee on Taxonomy of Viruses. Vienna (Springer).

Neumann-Held, E. M. (2001) Let's talk about genes: the process molecular gene concept and its context. In: S. Oyama, P. Griffiths \& R. Gray (ed.), Cycles of contigency - Developmental systems and evolution, Cambridge (MIT Press): 69-84.

Nola, R. \& Sankey, H. (2007) Theories of scientific method. Stocksfield (Acumen Publishers).

Padidam, M., Sawyer, S., Fauquet, C. M. (1999) Possible emergence of new geminiviruses by frequent recombination. Virology, 265: 218-225. <http://dx.doi.org/10.1006/viro.1999.0056>

Pigliucci, M. (2003) Species as family resemblance concepts: the (dis-) solution of the species problem? BioEssays, 25: 596-602. <http://dx.doi.org/10.1002/bies.10284>

Ponomarenko, J. V. \& Van Regenmortel, M. H. V. (2009) B cell epitope prediction. In: J. Gu \& P. E. Bourne (ed.), Structural bioinformatics, Second edition, John Wiley \& Sons Inc. pp. 849-879.

Pringle, C. R. (1991) The 20th meeting of the executive committee of the ICTV. Virus species, higher taxa, a universal database and other matters. Archives of Virology, 119: 303-304. <http://dx.doi.org/10.1007/BF01310680>

Quine, W. V. (1960) Word and object. Cambridge (MIT Press). 
Quine, W. V. (1990) Classes versus properties. In: Quiddities: an intermittently philosophical dictionary, London (Penguin Books): 22-24.

Quine,W. V.\& Ullian, J. S. (1978) The web of belief. New-York (McGraw-Hill): 44.

Radoshitzky, S. R., Bào, Y., Buchmeier, M. J., Charrel, R. N., Clawson, A. N., Clegg, C. S., De Risi, J. L., Emonet, S., Gonzalez, J. P., Kuhn, J. H., Lukashevich, I. S., Peters, C. J., Romanowski, V., Salvato, M. S., Stenglein, M. D. \& de la Torre, J. C. (2015) Past, present, and future of arenavirus taxonomy. Archives of Virology, 160: $1851-1874$. $<$ http://dx.doi.org/10.1007/s00705-015-2418-y>

Ruse, M. (1987) Biological species: natural kinds, individuals, or what? The British Journal for the Philosophy of Science, 38: 225-242. <http://dx.doi.org/10.1093/bjps/38.2.225>

Van Regenmortel, M. H. V. (1989) Applying the species concept to plant viruses. Archives of Virology, $104: 1-17$. $<$ http://dx.doi.org/10.1007/BF01313804>

Van Regenmortel, M. H. V. (1990) Virus species: a much overlooked but essential concept in virus classification Intervirology, $31: 241-254$.

Van Regenmortel, M. H. V. (2000) Introduction to the species concept. In: M. H. V. Van Regenmortel, C. M. Fauquet, D. H. L. Bishop, E. B. Carstens, M. K. Estes, S. M., Lemon, J. Maniloff, M. A. Mayo, D. J. McGeoch, C. R. Pringle \& R. B. Wickner (2000) Virus taxonomy. Seventh Report of the International Committee on Taxonomy of Viruses, New York \& San Diego (Academic Press): 3-16.

Van Regenmortel, M. H. V. (2001) Perspectives on binomial names of virus species. Archives of Virology, 146: 1637-1640. <http://dx.doi.org/10.1007/s007050170086>

Van Regenmortel, M. H. V. (2003) Viruses are real, virus species are man-made taxonomic constructions. Archives of Virology, 148: 2483-2490. <http://dx.doi.org/10.1007/s00705-003-0246-y>

Van Regenmortel, M. H. V. (2006) Virologists, taxonomy and the demands of logic. Archives of Virology, 159: 1251-1255. <http://dx.doi.org/10.1007/s00705-006-0786-z>

Van Regenmortel, M. H. V. (2007) Virus species and virus identification: past and current controversies. Infection, Genetics \& Evolution, 7: 133-144. <http://dx.doi.org/10.1016/j.meegid.2006.04.002>

Van Regenmortel, M. H. V. (2010a) Logical puzzles and scientific controversies: the nature of species, viruses and living organisms. Systematic \& applied Microbiology, 33: 1-6. <http://dx.doi.org/10.1016/j.syapm.2009.11.001>

Van Regenmortel, M. H. V. (2010b) Virus species. In: B. W. J. Mahy \& M. H. V. Van Regenmortel (ed.), Desk encyclopedia of general virology, San Diego (Elsevier): 37-41.

Van Regenmortel, M. H. V. (2011) Virus species. In: M. Tibayrenc (ed.), Genetics and evolution of infectious diseases, London, Burlington (Elsevier): 3-19. <http://dx.doi.org/10.1016/B978-0-12-384890-1.00001-7>

Van Regenmortel, M. H. V. (2016) The metaphor that viruses are living is alive and well, but it is no more than a metaphor. Studies in History \& Philosophy of biological and biomedical Sciences, 59: 117-124.

Van Regenmortel, M. H. V., Ackermann, H.-W., Calisher, C. H., Dietzgen, R. G., Horzinek, M., Keil, G. M., Mahy, B. W. J., Martelli, G. P., Murphy, F. A., Pringle, C., Rima, B. K., Skern, T., Vetten, H.-J. \& Weaver, S. C. (2013) Virus species polemics: 14 senior virologists oppose a proposed change to the ICTV definition of virus species. Archives of Virology, 158: 1115-1119. <http://dx.doi.org/10.1007/s00705-012-1583-5>

Van Regenmortel, M. H. V., Bishop, D. H. L., Fauquet, C. M., Mayo, M. A., Maniloff, J. \& Calisher, C. H. (1997) Guidelines to the demarcation of virus species. Archives of Virology, 142: 1505-1518.

Van Regenmortel, M. H. V., Burke, D. S., Calisher, C. H., Dietzgen, R. G., Fauquet, C. M., Ghabrial, S. A., Jahrling, P. B., Johnson, K. M., Holbrook, M. R., Horzinek, M. C., Keil, G. M., Kuhn, J. H., Mahy, B. W., Martelli, G. P., Pringle, C., Rybicki, E. P., Skern, T., Tesh, R. B., Wahl-Jensen, V., Walker, P. J. \& Weaver, S. C. (2010) A proposal to change existing virus species names to non-Latinized binomials. Archives of Virology, 155: $1909-1919$. $<$ http://dx.doi.org/10.1007/s00705-010-0831-9>

Van Regenmortel, M. H. V. \& Fauquet, C. M. (2002) Only italicized species names of viruses have a taxonomic meaning. Archives of Virology, 147: 2247-2250. <http://dx.doi.org/10.1007/s007050200050>

Van Regenmortel, M. H. V. \& Mahy, B. W. J. (2004) Emerging issues in viral taxonomy. Emerging infectious Diseases, 10: $8-13 .<$ http://dx.doi.org/10.3201/eid1001.030279>

Van Regenmortel, M. H. V., Mayo, M. A., Fauquet, C. M. \& Maniloff, J. (2000) Virus nomenclature: consensus versus chaos. Archives of Virology, 145: 2227-2232. <http://dx.doi.org/10.1007/s007050070053>

Van Rijsbergen, K. (1979) Information retrieval. Second edition. London (Butterworths).

Varsani, A., Martin, D. P., Navas-Castillo, J., Moriones, E., Hernandez-Zepeda, C., Idris, A., Zerbini, F. M. \& Brown, J. K. (2014) Revisiting the classification of curtoviruses based on genome-wide pairwise identity. Archives of Virology, 159: 1873-1882. <http://dx.doi.org/10.1007/s00705-014-1982-x> 
Vetten, H. J. \& Haenni, A.-L. (2006) Taxon-specific suffixes for vernacular. Archives of Virology, 151: 1249-1250. $<$ http://dx.doi.org/10.1007/s00705-006-0743-x>

Villarreal, L. P. (2010) Evolution of viruses. In: B. W. J. Mahy \& M. H. V. Van Regenmortel (ed.), Desk encyclopedia of general virology, San Diego (Elsevier): 70-80.

Wildy, P. (1971) Classification and nomenclature of First Report of the International Committee on Nomenclature of Viruses. Monographs in Virology, 5, Basel (Karger).

Wolf, U. (1995) The genetic contribution to the phenotype. Human Genetics, 95: 127-148. <http://dx.doi.org/10.1007/ BF00209392>

Submitted: 13 May 2015. Accepted: 8 January 2016. Published: 11 November 2016. Corresponding editor: Alain Dubois. 